\title{
ACADEMIC PROCRASTINATION OF COLLEGE STUDENTS
}

\author{
Grace Amin \\ Management, Universitas Presiden Cikarang \\ Email: grace_amin@president.ac.id
}

Masuk : 22-07-2019, revisi: 29-09-2019, diterima untuk diterbitkan : 30-10-2019

\begin{abstract}
ABSTRAK
Penundaan atau prokastinasi dapat diartikan sebagai kecenderungan menunda pengerjaan atau penyelesaian suatu tugas atau aktifitas. Ada banyak factor yang empengaruhi penundaan akademik seperti kecanduan internet, self efficacy, manajemen waktu, motivasi dan stress. Salah satu dampak dari penundaan akademik adalah hasil akademik. Tujuan dari penelitian ini adalah untuk menganalisa factor yang mempengaruhi academic procrastination diantara mahasiswa di wilayah Cikarang - Bekasi. Peneliti menganalisa data yang didapatkan dari hasil 139 mahasiswa yang telah mengisi kuesioner menggunakan metode analisis jalur - PLS. Sampel yang digunakan dalam penelitian ini adalah mahasiswa angkatan 2016 - 2019. Hasil dari penelitian ini menunjukkan bahwa sebagian besar hipotesis yang diajukan diterima. Beberapa hipotesis menyatakan bahwa kecanduan internet tidak memiliki dampak yang signifikan terhadap manajemen waktu, kecanduan internet tidak memiliki dampak yang signifikan terhadap academic procrastination melalui manajemen waktu, motivasi tidak memiliki dampak yang signifikan terhadap academic procrastination, Stress tidak memiliki dampak yang signifikan terhadap manajemen waktu dan stress tidak memiliki dampak signifikan terhadap academic procrastination melalui manajemen waktu.
\end{abstract}

Kata Kunci: Academic Procrastination, Kecanduan internet, Self-Efficacy, Manajemen Waktu, Motivasi, Stress

\begin{abstract}
Procrastination refers to intentionally delay in the beginning or completion of due tasks or activities. There are many factors influencing academic procrastination, such as internet addiction, self - efficacy, time management, motivation and stress. One of the impacts of academic procrastination is academic performance. The purpose of this research is to analyze factors influence procrastination among college students in Cikarang - Bekasi. Researcher analyzed data that gathered from 139 students filled the questionnaire, using path analysis - PLS. Sample in this research were college students batch 2016 - 2019. The result of this research show that most of proposed hypotheses in the model were accepted. Some hypotheses stated that Internet Addiction has no significant effect on time management, Internet Adiction has no significant indirect effect on academic procrastination through time management, Motivation has no significant effect on academic procrastination, Stress has no significant effect on time management and stress has no significant effect on academic procrastination through time management.
\end{abstract}

Keywords: Academic Procrastination, Internet Addiction, Self-Efficacy, Time Management, Motivation, Stress

\section{INTRODUCTION}

\section{Background}

Academic procrastination can be defined as the tendency to postpone and delay academic tasks or ignoring academic responsibility during the entire course of studies. The indicators of academic procrastination are postpone or delay to start doing of the task, delay finishing or submitting the assignments, pass over the deadline of task that has been planned and do other interesting activities than finishing the tasks. It is a common behavior that college students do during their academic period. For example, students postpone the preparation and submission of their assignments or presentations, completing projects, or even preparing their final examination. Research done by previous researchers found that $30 \%-60 \%$ of university students report their regular postponement. Academic Procrastination influence student's academic performance. (Hussain \& Sultan,2010;Rabin,Fogel\&Nutter-Upham,2011; Hadiwijaya et al., 2014;Peng \& 
Kamil, 2017) Universities already set the period of study and every student must finish their study during that period. Through academic period, college students have many obligations should be fulfilled. For some students, these obligations are considered as challenge. In the other hand there are many students make those obligations as obstacles should be avoided. (Adrianta \& Tjundjing, 2007; Handaru, Lase, \& Parimita, 2014; Hussain \& Sultan, 2010; Uzun \& Unal, 2014).

In the education field, students facing many stressors such as assignments, deadline of projects, or academic activities. Stress is a negative emotional experience and tension caused by internal and external factors. As stressors accumulate, an individual's ability to cope or readjust can be overtaxed, depleting their physical or psychological resources. In turn, there is an increased probability that physical illness or psychological distress will follow. Reactions to stressors refer to the state of physical or psychological arousal that usually results from the perception of stress. Students experience physical and psychological reactions to stressors when they perceive excessive or negative stress. Excessive stress induces physical impairments, and it is not uncommon to find students afflicted with persistent lack of energy, loss of appetite, headaches, or gastrointestinal problems. In addition, some international students may somaticize their feelings of stress to avoid the stigma of seeking psychological assistance. Psychological distress is reported especially among those who fail to succeed academically. Many international students rank in the top levels of their native country schools, and their expectations about academic performance in a new educational environment may be unrealistically high. Furthermore, additional pressures to obtain financial support that is often limited for international students con- tributes to their stress. Consequently, lack of traditional social support, high academic achievement, and financial aid restrictions are a few of the critical stressors international students encounter (Misra \& Castillo, 2004; Shadi, et.al, n.d.)

Assignments or projects those felt difficult by students sometimes make students lose their confidence and give up. It can be caused by low self - efficacy and motivation. Perceived self efficacy can be defined as people's beliefs about their capabilities to produce designated levels of performance that influence over events and affect their lives. Self- efficacy determines how people feel, think and motive themselves to behave. Level of difficulty, strength and confidence are factors influencing self - efficacy. (Damri, Engkizar, \& Anwar, 2017;Rogelberg, 2017) On the other hand, motivation can be defined as activation of goal-oriented behavior. It also can be referring to effort to do something. Motivation defined into internal and external motivation. Internal motivation refers to motivation that is driven by an interest or enjoyment in the task itself and exists within the individual. In contrast, external motivation leads to tangible benefits such as rewards those drive someone to do something. (Cabot, 2016; Cetin, 2016; Singh, 2011) Frequently students are not able to manage their time or just make priority tasks to do. They are able to manage their time. Time management is the act or planning and exercising conscious control over the amount of time spent on specific tasks or activities, to increase effectiveness, efficiency and productivity. Factors those indicate someone manage their time well are able to determine the target and arrange the priority, planning and scheduling, able to organize the job and time. (Forrel, 2017; Heap, 2008).

There are many college students those prefer playing online games or surfing in the internet than finishing their assignments. Internet addiction refers to excessive internet use, compulsive computer uses. There are some indicators of people with this addiction, such as enjoy the activities using internet, can not control their time when using internet and feel panic, nervous and aggressive when there is no internet connection. (Hussain \& Sultan, 2010; Uzun \& Unal, 2014; Mihajlov, M., \& Vejmelka, L, 2017, Demir \& Kutlu, 2018) 
Based on observation, researcher find that the number of academic procrastinations, such as delay of thesis, assignment, projects or presentations submission, increase every year. Researcher also tried to interview academic staffs in some universities and found the same phenomenon. Procrastination can be caused by stress, internet addiction, self - efficacy, time management, motivation and frequently impact to students' academic performance. (Hadiwijaya, et.al, 2015, Uzun \& Unal, 2014)

Based on the description above, this research wants to analyze factors influence academic procrastination as follows:

1. Is there any direct effect of internet addiction towards time management of college students?

2. Is there any indirect effect of internet addiction towards academic procrastination of college students through time management?

3. Is there any direct effect of internet addiction towards academic procrastination of college students?

4. Is there any direct effect of motivation towards time management of college students?

5. Is there any indirect effect of motivation towards academic procrastination of college students through time management?

6. Is there any direct effect of motivation towards academic procrastination of college students?

7. Is there any direct effect of self - efficacy towards time management of college students?

8. Is there any indirect effect of self - efficacy towards academic procrastination of college students through time management?

9. Is there any direct effect of self - efficacy towards academic procrastination of college students?

10. Is there any direct effect of stress towards time management of college students?

11. Is there any indirect effect of stress towards academic procrastination of college students through time management?

12. Is there any direct effect of stress towards academic procrastination of college students?

13. Is there any direct effect of time management towards academic procrastination of college students?

\section{RESEARCH METHOD}

The research uses the quantitative method to measure and analyze the collected data which is gained through questionnaires that are spread to the respondents. The study analyzes the relation of all variables related to the research problem. Researcher spread the question directly to the students and also use Social Medias, including Line, WhatsApp, and Instagram.

Population is all related things or cases which are included as our subject of research; it does not always have to be described in an exact number (Etikan et al., 2016). The population in this research were college student batch 2016 - 2019. The technique of sampling that is used in this research is purposive sampling. Researcher choose participants those have similar characteristics with the research. Stated by Sarwono (2015), the minimum sample size for the research by PLS ideally is 10 times the total largest number of questionnaire from the indicators. Thus, to measure how many samples to be analyzed in the study, the researcher calculates with the following formula:

Eq. 3.1 Sample Measurement

$$
\mathbf{N}=\mathbf{1 0} \times \mathbf{Q}=10 \times 7=70
$$


Where,

$\mathrm{N}=$ Number of Questionnaire

$\mathrm{Q}=$ Total number of questions from the variables with the most indicators

The minimum number of samples that should be analyzed from the population are 70 samples, meanwhile, the research had gained 139 samples to be analyzed in the research.

Researcher used Partial Least Square (PLS) to analyze the relation between a set of latent independent variables to the multiple dependent variables in a model (Hair et al., 2018).

\section{RESULT AND DISCUSSION}

The respondents in this research are students from some universities. Researcher had collected data by spread questionnaires to 139 respondents. Based on the result, the information related to the respondent's demographic data is shown as the followings.

Table 1 Respondents' Profile

Source: SPSS

\begin{tabular}{|c|c|c|c|}
\hline \multirow{2}{*}{ Criteria } & Classification & $\begin{array}{c}\text { Number of } \\
\text { respondents }\end{array}$ & Percentage \\
\hline \multirow{3}{*}{ Batch } & 2016 & 15 & $10.8 \%$ \\
\cline { 2 - 4 } & 2017 & 37 & $26.6 \%$ \\
\cline { 2 - 4 } & 2018 & 77 & $55.4 \%$ \\
\cline { 2 - 4 } & 2019 & 10 & $7.2 \%$ \\
\hline \multirow{5}{*}{ Gender } & Female & 96 & $69.1 \%$ \\
\cline { 2 - 4 } & Male & 43 & $30.9 \%$ \\
\hline
\end{tabular}

Based on the data, most of the respondents are female students (69.1\%), batch $2018(55.4 \%)$

\section{Outer Model Measurement}

The step for the Outer Model Measurement will be the same with the step for the Pre-Test in the research. The outer model will be analyzed based on the convergent validity, discriminant validity and reliability of internal consistency. The relation of the indicators towards the variables in the research is known as the outer loading, which will be analyzed based on the convergent and discriminant validity and also the internal consistency reliability. AVE or Average Variance Extracted is the score that can be used to test convergent validity. In a good model, the AVE should score at least 0.5 or higher as it means that the latent variables may explain at least half of the indicator variances (Sarwono, 2015). Besides the score of AVE, the value of outer loading factor should also be measured as it shows the relation between the latent variables and its indicators. The value of outer loading factor should score above 0.60 to show that the variables and indicators are tightly related to each other. VIF or Variance Inflation Factor is used to analyze whether there is any collinearity between the indicators. Ideally, it will be better for the model to have a VIF close to 5 and lower. If the score of VIF is higher than 5, then there is a possibility that multicollinearity exist in the model (Akinwande et al., 2015).

Besides the score of VIF, it is also important to find the Fornell-Larcker Criterion in order to detect the discriminant validity. All the values of Fornell \& Lercker are all higher than the constructs' values that are located in the same row and column. This means that the latent variable is able to explain its own indicator's variance better than the variance of other construct's indicators (Garson, 2016; Hair et al., 2018). Cronbach's Alpha is used to measure the reliability of all indicators in the model. The minimal score of Cronbach's Alpha is said to be acceptable is 0.60 (Hair et al., 2018). Other than Cronbach's Alpha, it is also necessary to 
measure the Composite Reliability of the model. The ideal Composite Reliability should score higher than 0.70 (Sarwono, 2015) as it may help to measure better that the indicators in the research is the true representative indicators that construct the variables of the model (Garson, 2016). In order to make it valid, the researcher delete some indicators those couldn't fit with the criteria. Thus, all the variables in the research are considered valid and reliable.

Table 3 Result of Loading factors, VIF, AVE, Cronbach's Alpha, Rho and Composite Reliability Source: SmartPLS (2019)

\begin{tabular}{|c|c|c|c|c|c|c|c|}
\hline Variables & $\begin{array}{c}\text { Sub } \\
\text { Variables }\end{array}$ & $\begin{array}{c}\text { Outer } \\
\text { Loading }\end{array}$ & $\begin{array}{c}\text { Model } \\
\text { VIF }\end{array}$ & AVE & $\begin{array}{c}\text { Cronbach's } \\
\text { Alpha }\end{array}$ & Rho_A & $\begin{array}{l}\text { Composite } \\
\text { Reliability }\end{array}$ \\
\hline \multirow{4}{*}{$\begin{array}{c}\text { Academic } \\
\text { procrastination }\end{array}$} & AP1 & 0.745 & 1.599 & \multirow[t]{4}{*}{0.611} & \multirow[t]{4}{*}{0.789} & \multirow[t]{4}{*}{0.806} & \multirow[t]{4}{*}{0.862} \\
\hline & AP2 & 0.842 & 1.744 & & & & \\
\hline & AP3 & 0.803 & 1.647 & & & & \\
\hline & AP5 & 0.733 & 1.401 & & & & \\
\hline \multirow{4}{*}{$\begin{array}{c}\text { Time } \\
\text { Management }\end{array}$} & TM3 & 0.809 & 1.968 & \multirow[t]{4}{*}{0.646} & \multirow[t]{4}{*}{0.822} & \multirow[t]{4}{*}{0.839} & \multirow[t]{4}{*}{0.880} \\
\hline & TM4 & 0.816 & 2.102 & & & & \\
\hline & TM5 & 0.818 & 2.091 & & & & \\
\hline & TM7 & 0.773 & 1.326 & & & & \\
\hline \multirow{3}{*}{$\begin{array}{c}\text { Internet } \\
\text { Addiction }\end{array}$} & IA1 & 0.836 & 1.495 & \multirow[t]{3}{*}{0.631} & \multirow[t]{3}{*}{0.714} & \multirow[t]{3}{*}{0.761} & \multirow[t]{3}{*}{0.836} \\
\hline & IA2 & 0.857 & 1.461 & & & & \\
\hline & IA3 & 0.679 & 1.300 & & & & \\
\hline \multirow{4}{*}{ Motivation } & M1 & 0.726 & 1.250 & \multirow[t]{4}{*}{0.534} & \multirow[t]{4}{*}{0.715} & \multirow[t]{4}{*}{0.732} & \multirow[t]{4}{*}{0.820} \\
\hline & M2 & 0.827 & 1.600 & & & & \\
\hline & M3 & 0.697 & 1.289 & & & & \\
\hline & M5 & 0.664 & 1.413 & & & & \\
\hline \multirow[t]{4}{*}{ Self - Efficacy } & SE1 & 0.702 & 1.498 & \multirow[t]{4}{*}{0.611} & \multirow[t]{4}{*}{0.790} & \multirow[t]{4}{*}{0.807} & \multirow[t]{4}{*}{0.862} \\
\hline & SE3 & 0.799 & 1.983 & & & & \\
\hline & SE5 & 0.851 & 1.971 & & & & \\
\hline & SE6 & 0.767 & 1.423 & & & & \\
\hline \multirow{4}{*}{ Stress } & STRES4 & 0.798 & 1.940 & \multirow[t]{4}{*}{0.571} & \multirow[t]{4}{*}{0.755} & \multirow[t]{4}{*}{0.755} & \multirow[t]{4}{*}{0.842} \\
\hline & STRES5 & 0.747 & 1.391 & & & & \\
\hline & STRES6 & 0.753 & 1.687 & & & & \\
\hline & STRES7 & 0.722 & 1.274 & & & & \\
\hline
\end{tabular}

Table 4 Fornell \& Larcker

Source: SmartPLS (2019)

\begin{tabular}{|c|c|c|c|c|c|c|}
\hline Variables & AP & IA & MTV & SE & STRES & TM \\
\hline AP & 0.782 & & & & & \\
\hline IA & 0.504 & 0.794 & & & & \\
\hline MTV & -0.084 & -0.072 & 0.731 & & & \\
\hline SE & 0.033 & -0.045 & 0.630 & 0.782 & & \\
\hline STRES & 0.380 & 0.272 & -0.160 & -0.096 & 0.756 & \\
\hline TM & -0.242 & -0.136 & 0.546 & 0.584 & -0.068 & 0.084 \\
\hline
\end{tabular}




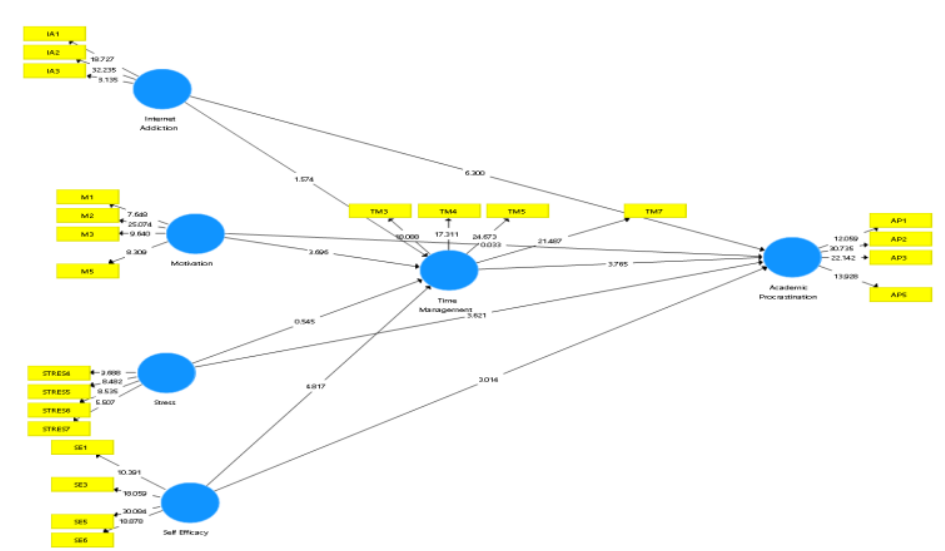

Figure 1 Outer Model

\section{Inner Model Measurement}

Besides to measure the outer model, it is also important to measure the inner model. In order to measure the inner model of the research, the researcher performed the measurement towards RSquare and path coefficients. The R-Square value will determine whether the latent variables represent the effects towards the research.

Table 5 R-square

Source: SmartPLS (2019)

\begin{tabular}{|l|c|}
\hline & R-square \\
\hline Academic procrastination & 0.392 \\
\hline Time Management & 0.405 \\
\hline
\end{tabular}

The R-square from table above shows the percentage of impacts Motivation, Stress, Internet Addiction and Self - Efficacy towards Academic procrastination and Time Management, which are 0.392 and 0.405 respectively. It can be conclude that Motivation, Stress, Internet Addiction and Self - Efficacy represent 40.5 percent effects towards Time Management and all of the independent variables represent 39.2 percent effects towards Academic procrastination in this study. The value of $\mathrm{R}$-square of the effects towards academic procrastination and time management shows a weak to moderate effects to explain the research model (Hair et al., 2018). Path Coefficient of the research model will be important to analyze whether the variable has any effects towards the others. The path coefficient can be measured by the score of $p$-values. The score of p-value should be smaller or equal to 0.05 for the effects to be considered significant (Garson, 2016).

Table 6 Path Coefficient

Source: SmartPLS (2020)

\begin{tabular}{|l|l|c|c|c|}
\hline Hypothesis & \multicolumn{1}{|c|}{ Relationship } & T Values & P Values & Decision \\
\hline H1 & IA -> TM & 1.574 & 0.116 & Rejected \\
\hline H2 & IA -> TM -> AP & 1.467 & 0.143 & Rejected \\
\hline H3 & IA -> AP & 6.300 & 0.000 & Accepted \\
\hline H4 & MTV -> TM & 3.696 & 0.000 & Accepted \\
\hline H5 & MTV -> TM -> AP & 2.650 & 0.008 & Accepted \\
\hline H6 & MTV -> AP & 0.033 & 0.974 & Rejected \\
\hline H7 & SE -> TM & 4.817 & 0.000 & Accepted \\
\hline H8 & SE -> TM -> AP & 2.852 & 0.005 & Accepted \\
\hline H9 & SE -> AP & 3.014 & 0.003 & Accepted \\
\hline H10 & Stress -> TM & 0.545 & 0.586 & Rejected \\
\hline
\end{tabular}




\begin{tabular}{|l|l|l|l|l|}
\hline H11 & Stress ->TM -> AP & 0.536 & 0.592 & Rejected \\
\hline H12 & Stress -> AP & 3.621 & 0.000 & Accepted \\
\hline H13 & TM -> AP & 3.765 & 0.000 & Accepted \\
\hline
\end{tabular}

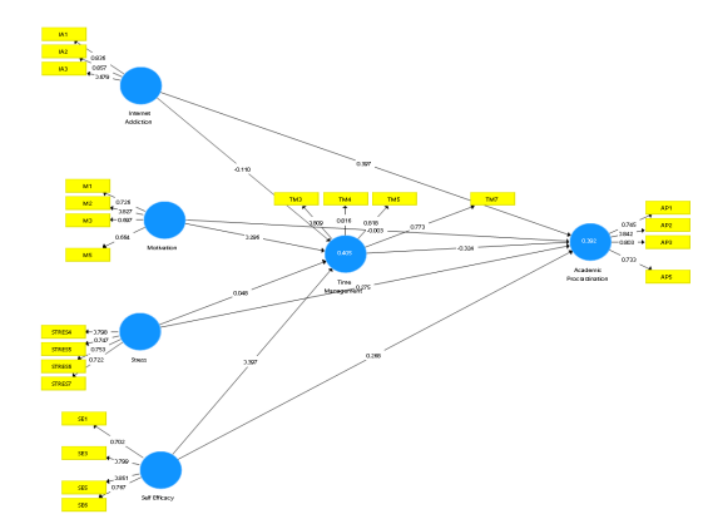

Figure 2 Measurement of Inner Model Source: SmartPLS (2020)

\section{Interpretation of Results}

This research aimed to analyze the significant influence of Internet Addiction, Motivation, Self Efficacy and Stress on Academic procrastination of college students. This research also analyzed the mediating influence of Time Management. The result will be explain more detail in the following sections.

\section{The Influence of Internet Addiction, Time Management and Academic procrastination}

The result of this research show that there is no significant direct effect of internet addiction to time management. Based on the result the p-value is 0.116 , which is higher than 0.05 and $t$-value is 1.574 , which is lower than 1.96. It also happened to the indirect effect of internet addiction to academic procrastination through time management. As we can see the $\mathrm{p}-$ value is 0.077 and $\mathrm{t}-$ value of 1.77. It means the students those have internet addiction can not significantly manage their time well. It also means that they will not significantly do academic procrastination because they can not manage their time. Different with the previous hypothesis, based on the result that can be seen at table 6 , the value of p-value is 0.000 , and $t$ - value is 6.300 , which means that the Internet Addiction does have a significant direct effect towards academic procrastination. When students addict to internet, they can feel worry if they can not get internet access. They tend to be only focus on the internet and forget about other activities. This addiction make the students are not able to arrange their target, schedule or priority of tasks. They can not organize their project systematically or finish their task on time.They tend to postpone their assignments and pass over the project's deadline that has been planned. This result is also supported by some previous researches such as Hussain \& Sultan (2010), Demir \& Kutlu, (2018) and Mihajlov \& Vejmelka (2017). Previous research found that one factor that affects academic procrastination is internet addiction. The Internet is used extensively among adolescents. This situation causes adolescents to postpone or not to carry out their duties and responsibilities related to school. Therefore, it can be said that academic procrastination has increased as the duration of internet usage increases. Specifically, excessive internet use of school-age youth increases their academic procrastination and decreases their academic motivation by adversely affecting their psychological and physical development and social relations. Similarly, intensive internet use in adolescents causes them to not fulfill their academic goals or to decrease the quality time they spend for these purposes. 


\section{The Effect of Motivation, Time Management and Academic procrastination}

From table 6, we can see that motivation has insignificant direct effect to academic procrastination. The result of $\mathrm{p}$-value is 0.974 , and $\mathrm{t}-$ value is 0.033 This result show us that even if the students have low motivation in the college, it does not have significant direct effect to their academic procrastination. Contrast with the previous hyphothesis, the result of this research show that there is significant direct effect of motivation toward time management where the $\mathrm{p}$ - values is 0.000 and $\mathrm{t}-$ value 3.696. The indirect effect of motivation to academic procrastination through time management also significant. As we can see the $\mathrm{p}-$ value is 0 . 0.008 , which is lower than 0.05 , and $\mathrm{t}-$ value of 2.650 which is higher than 1.96 . It means the students those have low motivation to get any achievement in their college significantly will not put study as their priority and do academic procrastination. When students have no interest or enjoyment in their task or major and external reward to do it, they will not put their college's tasks as priority and do their tasks effectively. The students have to like and enjoy their college life in order to increase their motivation. This result is supported by previous researchs done by Singh (2011) and Cetin (2016). They have to find the purpose of their life, the importance of their study in the future so that they can build a big effort to achieve their dream by manage their time and not postponing any important tasks. Support from students' parents and lecturers also needed by the students.

\section{The Effect of Self Efficacy, Time Management and Academic procrastination}

In this research, all hypothesis about the effect of self efficacy, time management and academic procrastination are accepted. This research found that there is significant direct effect of self efficacy on time management. Based on the result that can be seen at table 6 , the value of $p$-value is 0.000 and $t$ - value is 4.817 which is higher than 1.96. This research also found that there is significant indirect effect of self - efficacy on academic procrastination through time management by $\mathrm{p}$ value $=0.005$ and $\mathrm{t}$ value $=2.856$. The last hypothesis also support the previous hypothesis. Based on the value of $\mathrm{p}-$ value $=0.003$ and $\mathrm{t}-$ value $=3.014$, stated that self-efficacy has significant direct effect on academic procrastination. This result explained to us that students' belief about their capabilities to produce designated level of performance that influence over events and affect their lives are going to push them to plan their lives. They will control the amount of time spent on specific tasks or activities in order to increase effectiveness, efficiency and productivity. They shall not wasting their time or postpone something they can do earlier. In contrast, students those have no high confidence about their capabilities tend to has no plan about their life and do something useless. This result is inline with some previous research done by Damri, Engkizar, \& Anwar, (2017) and Rogelberg, 2017.

\section{The Effect of Stress, Time Management and Academic procrastination}

From table 6, we can see that stress has no significant direct effect to time management. The result of $p$-value is 0.586 , and $t-$ value is 0.545 . The result of stress effect towards academic procrastination through time management also insignificant. The $\mathrm{p}$ value is 0.592 and $t$ value is 0.536. Negative emotional experience and tension caused by internal and external factors are going to insignificantly influence students' abilities to manage their schedule and cause postponement of finishing tasks.

Contrast with the previous result, the direct effect of stress on academic procrastination is significant. As we can see in table 6 , the $p$ value is 0.000 and $t$ value is 3.621 . It can be concluded that students those can not deal with their tension or stress are going to delay the beginning and finishing the assignments. Reactions to stressors refer to the state of physical or psychological arousal that usually results from the perception of stress. Students experience physical and 
psychological reactions to stressors when they perceive excessive or negative stress. Excessive stress induces physical impairments, and it is not uncommon to find students afflicted with persistent lack of energy, loss of appetite, headaches, or gastrointestinal problems. In addition, some international students may somaticize their feelings of stress to avoid the stigma of seeking psychological assistance. Psychological distress is reported especially among those who fail to succeed academically. Those symtomps can influence their time management and tendency of procrastination. This research also supported by some previous researchers such as Adrianta \& Tjundjing, (2007) and Hussain \& Sultan (2010).

\section{The Effect of Time Management on Academic procrastination}

This research, as previous research by Heap (2008); Hussain \& Sultan (2010) and Forrel (2017); found that there is significant direct effect of time management on academic procrastination. Based on the result that can be seen at table 6 , the value of p-value is 0.000 , lower than 0.05 , and $\mathrm{t}$ - value is 3.765, which is higher than 1.96. This result explained to us that students' ability to manage their time will prevent academic procrastination occur. As we know time management is the act or planning and exercising conscious control over the amount of time spent on specific tasks or activities, to increase effectiveness, efficiency and productivity. Factors those indicate someone manage their time well are able to determine the target and arrange the priority, planning and scheduling, able to organize the job and time.Students will control the amount of time spent on specific tasks or activities in order to increase effectiveness, efficiency and productivity. They shall not wasting their time or postpone something they can do earlier. In contrast, students those have no plan, priority or purpose of life tend to postpone something important and do something useless.

\section{CONCLUSION AND RECOMMENDATION}

The research aims to examine further the Academic Procrastination among college students. Based on the result that has been elaborate in the previous chapter, the researcher concluded the results as the followings.

1. There is no significant direct effect of internet addiction towards time management of college students

2. There is no significant indirect effect of internet addiction towards academic procrastination of college students through time management

3. Internet addiction has significant direct effect towards academic procrastination of college students

4. Motivation has significant direct towards time management of college students

5. There is significant indirect effect of motivation towards academic procrastination of college students through time management

6. There is no significant direct effect of motivation towards academic procrastination of college students

7. Self - efficacy has significant direct effect towards time management of college students

8. There is significant indirect effect of self - efficacy towards academic procrastination of college students through time management

9. Self - efficacy has significant direct effect towards academic procrastination of college students

10. There is no significant direct effect of stress towards time management of college students

11. There is no significant indirect effect of stress towards academic procrastination of college students through time management

12. Stress has significant direct effect towards academic procrastination of college students 
13. Time management has significant direct effect towards academic procrastination of college students?

\section{Recommendation}

From the research, there are several recommendations that the researcher would like to give to several parties, including the Lecturers or Education institutions, Students and Future Researchers.

\section{Lecturers or Education Institutions}

Reflecting from the results of the research, it is important to create an educational environment that encourage students to explore their capabilities freely. An environment where bullying is forbidden and every student respect each other. By creating this comfort environment, students are going to increase their motivation and self - efficacy. Lecturers and education institution should appreciate students who achieve some boast achievement. Any appreciation given by lecturers will raise students' confidence and impact to their academic performance.

Although students are allowed to express their capabilities and expression freely, lecturers or education institutions also have to make reasonable regulation. Punishment can be given to any student that break the rules. By giving punishment and clear explanation about the reason of that punishment, students will learn some values needed in the future.

Lecturer and education institution also have to be trusted friend and good listener for their students. By being a good friend and listener, lecturer can support students when they facing problems.

\section{Students}

This research show us that motivation, internet addiction, stress and self - efficacy have effect on time management and academic procrastination so it will be better for students to manage their time well. Students should belief in their capabilities or talents those have been given by God. They have to use their time to explore some interesting, new and useful thing. Internet can be used to help them finishing what they planned before. If the students already fill their time for something important, they will know the meaning of time for their life.

\section{Future Researchers}

It would also be better for future researcher to find a larger sample or population that can cover bigger data. Future researchers also can find other variables besides those that are discussed in this research.

\section{Acknowledgement}

This research could not finished well without participation of all parties. Researcher would like to say thank to LRPM Universitas Presiden who gave financial support, Faculty of Business and all students who helped this research.

\section{REFERENCE}

Adrianta, E., \& Tjundjing, S. (2007). Mahasiswa Versus Tugas : Prokrastinasi Akademik dan Conscientiousness. Jounal Anima, Indonesian Psychological, 22(4), 352-374. https://doi.org/10.1086/512671

Akinwande, M. O., Dikko, H. G., \& Samson, A. (2015). Variance Inflation Factor: As a Condition for the Inclusion of Suppressor Variable(s) in Regression Analysis. Open Journal of Statistics, 5, 754-767.

Cabot, I. (2016). Academic motivation. Pajares.pdf, (17), 1-23. 
Cetin, B. (2016). Academic Motivation And Approaches To Learning In Predicting College Students' Academic Achievement: Findings From Turkish And US Samples. Journal of College Teaching \& Learning (TLC), 12(2), 141. https://doi.org/10.19030/tlc.v12i2.9200

Demir \& Kutlu. 2018. Relationship among Internet Addiction, Academic Motivation, Academic Procrastination and School Attachment in Adolescents. International Online Journal of Education Sciences. Vol 10(5). Page 315 - 332. https://doi.org/10.15345/iojes.2018.05.020

Damri, D., Damri, D., Engkizar, E., \& Anwar, F. (2017). Hubungan Self-Efficacy Dan Prokrastinasi Akademik Mahasiswa Dalam Menyelesaikan Tugas Perkuliahan. JURNAL EDUKASI: Jurnal Bimbingan Konseling, 3(1), 74-95. https://doi.org/10.22373/je.v3i1.1415

Etikan, I., Musa, S. A., \& Alkassim, R. S. (2016). Comparison of Convenience Sampling and Purposive Sampling. American Journal of Theoretical and Applied Statistics, 5(1), 1-4. doi:10.11648/j.ajtas.20160501.11

Forrel, M. (2017). Time Management. Journal of Library Administration, 57(2), 215-222. Retrieved http://search.proquest.com.ezp.lib.unimelb.edu.au/docview/197221541 ?accountid=1237 2\% 5Cnhttp://sfx.unimelb.hosted.exlibrisgroup.com/sfxlcl41?url_ver=Z39.882004\&rft_val_fmt=info:ofi/fmt:kev:mtx:journal\&genre=article\&sid=ProQ:ProQ\%3Aed ucat ion \&atitle $=$ Time $+\mathrm{Ma}$

Garson, G. D. (2016). Partial Least Squares: Regression \& Structural Equation Models. Asheboro: Statistical Associates Publishing.

Hadiwijaya, K., et.al. 2014. Efikasi Diri Sebagai Moderator Hubungan antara Harapan Akademik, Prokrastinasi, dan Stres Akademik. Management Dynamics Conference.

Hair, J. F., Risher, J. J., Sarstedt, M., \& Ringle, C. M. (2018). When to use and how to report the results of PLS-SEM. European Business Review, 1-24. doi:10.1108/EBR-11-2018-0203

Handaru, A. W., Lase, E. P. S., \& Parimita, W. (2014). Analisis perbedaan tingkat prokrastinasi ditinjau dari gender, socio-personal, locus of control, serta kecerdasan emosional: studi pada mahasiswa program studi manajemen fe UNJ. Jurnal Riset Manajemen Sains Indonesia (JRMSI), 5(2), 243-263.

Heap, N. (2008). Time Management — . Journal of European Industrial Training, 3(3), 27-28. https://doi.org/10.1108/eb002315

Hussain, I., \& Sultan, S. (2010). Analysis of procrastination among university students. Procedia Social and Behavioral Sciences, 5(August), 1897-1904. https://doi.org/10.1016/j.sbspro.2010.07.385

Mihajlov, M., \& Vejmelka, L. (2017). Internet addiction: A review of the first twenty years.

Psychiatria Danubina, 29(3), 260-272. https://doi.org/10.24869/psyd.2017.260

Misra, R., \& Castillo, L. G. (2004). Academic stress among college students: Comparison of American and international students. International Journal of Stress Management, 11(2), 132-148. https://doi.org/10.1037/1072-5245.11.2.132

Peng, T.Z \& Kamil (2017). Time Management, Procrastination and Prioritazion : A Framework for Service Based Learning Module. E-Academia Journal. Vol 6 (2), 60 - 70

Rabin, L. A., Fogel, J., \& Nutter-Upham, K. E. (2011). Academic procrastination in college students: The role of self-reported executive function. Journal of Clinical and Experimental Neuropsychology, 33(3), 344-357. https://doi.org/10.1080/13803395.2010.518597 
Rogelberg, S. G. (2017). Self-Efficacy. The SAGE Encyclopedia of Industrial and Organizational Psychology, 2nd Edition, 4(1994), 71-81. https://doi.org/10.4135/9781483386874.n481

Sarwono, J. (2015). Membuat Skripsi, Tesis, dan Disertasi dengan Partial Least Square SEM (PLS-SEM). Yogyakarta: Penerbit Andi.

Shadi, M,et.al. (n.d.). Predictors of the academic stress and its determinants among students based on the theory of planned behavior.

Singh, K. (2011). Study of Achievement Motivation in Relation to Academic Achievement of Students. International Journal of Educational Planning \& Administration, 1(2), 2249- 3093.

Uzun.A \& Unal. 2014. Exploring Internet Addiction, Academic Procrastination and General Procrastination among Pre-Service ICT Teachers. Mevlana International Journal of Education Vol 4(1). April 2014 